\title{
Comparative evaluation of performance and usability of small-scale household composting with different geometric models
}

Avaliação comparativa de desempenho e usabilidade de composteiras domésticas com diferentes modelos geométricos

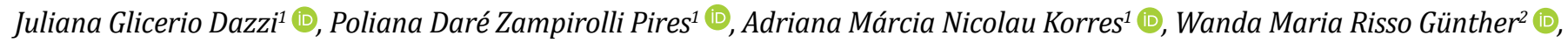

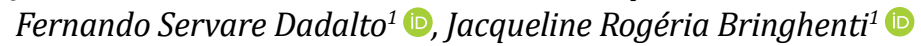

\section{A B S T RAC T}

The evaluation of layout influence on the operational performance and usability of small-scale composters contributes to produce compact solutions with simplified operation and sanitary safety, suitable for reduced spaces and continued use. This study aims to report the influence of different designs on the composting process and the usability of compost bins. Five composters of similar scale ( 3 liters) and different geometric shapes were designed, manufactured, and tested. Bench tests were carried out for 60 days, and physical, chemical, and sanitary parameters were monitored, as well as the quality of the compost, according to agronomic parameters. The composters were filled with the same proportions of organic residues (food residues, dry leaves, and lawn trimming) to obtain the ideal C: $\mathrm{N}$ ratio. Three geometrical layouts were tested concerning usability (hexagonal prism, cube, and parallelepiped) by volunteers for 50 days. The performed tests associated with the statistical treatment of results showed that the geometry of the prototypes interfered with the quality of the final compost and the composter operation. The hexagonal prism and the cube showed greater usability. The results represent a significant contribution to the advancement of solutions in decentralized composting.

Keywords: organic solid waste; valorization of solid waste; small-scale composting; composting bins; design.

\section{RE S U M 0}

A avaliação da influência do layout no desempenho operacional e na usabilidade de composteiras de pequena escala contribui para a obtenção de soluções compactas, de operação simplificada e sanitariamente seguras, adequadas a espaços reduzidos e uso continuado. Este artigo teve como objetivo relatar a influência de diferentes modelos geométricos no processo de compostagem e na usabilidade de composteiras. Cinco composteiras de escala similar (3,0 litros) e diferentes modelos geométricos foram projetadas, confeccionadas e testadas. Foram realizados testes de bancada por 60 dias, monitorando parâmetros físicos e químicos, aspectos operacionais e sanitários e a qualidade do composto segundo parâmetros agronômicos. As composteiras foram preenchidas com as mesmas proporções de resíduos orgânicos (resíduos alimentares, folhas secas e aparas de grama) para obter a relação $\mathrm{C} / \mathrm{N}$ ideal ao início do processo. Três layouts geométricos de composteiras foram testados quanto à usabilidade (prisma de base hexagonal, cubo e paralelepípedo) por voluntários durante 50 dias. Os testes em bancada associados ao tratamento estatístico dos resultados permitiram verificar que a geometria dos protótipos interferiu na qualidade do composto final e na operação da composteira. Os modelos geométricos de base hexagonal e cubo mostraram-se de maior usabilidade. Os resultados representam contribuição significativa para o avanço de soluções na compostagem descentralizada.

Palavras-chave: resíduos sólidos orgânicos; valorização de resíduos sólidos; compostagem descentralizada; equipamentos para compostagem; design.

\footnotetext{
${ }^{1}$ Instituto Federal de Educação, Ciência e Tecnologia do Espírito Santo - Vitória (ES), Brazil.

${ }^{2}$ Universidade de São Paulo - São Paulo (SP), Brazil.

Correspondende address: Jacqueline Rogéria Bringhenti - Instituto Federal do Espírito Santo, Coordenadoria de Saneamento Ambiental Avenida Vitória, 1729 - Jucutuquara - CEP: 29040-780 - Vitória (ES), Brazil - E-mail: jacquelineb@ifes.edu.br

Conflicts of interest: the authors declare that there are no conflicts of interest.

Funding: Instituto Federal de Educação, Ciência e Tecnologia do Espírito Santo.
}

Received on: 04/14/2020. Accepted on: 09/29/2020

https://doi.org/10.5327/z2176-947820200757 


\section{Introduction}

Minimizing and valuing domestic waste are important strategies to address the challenges of solid waste management in the cities. Several countries adopt public policies concerning organic waste, also known as food waste, which expands the discussion on issues of combating hunger and sustainability, aligned with the Sustainable Development Goals (SDGs) 1 and 11 of the agenda approved by the United Nations for sustainable development, called "Agenda 2030" (ONU, 2015).

Organic waste is part of household waste composition and has an indirect relationship with the socioeconomic conditions of its generators. On average, the percentage of organic waste generated in developed countries (34.32\%) is lower than in developing countries (61.33\%) and underdeveloped countries (64.21\%) (FEIL; SPILKI; SCHREIBER, 2015).

Although it has great potential, organic waste has not been prioritized for recovery due to lack of specific segregation and considerable operational costs for its treatment. Once disposed of together with common waste, it represents a significant volume to be collected and transported to landfills, reducing its useful life and increasing the operational costs of these procedures. When discarded in an environmentally inappropriate manner, it can cause environmental impacts with effects on human health due to the degradation that generates leachate (an unpleasant odor) and attracts and proliferates disease vectors (GÜNTHER, 2005).

Dutra, Medeiros, and Gianelli (2019) indicate composting as an alternative to reduce negative environmental impacts resulting from the transport and final destination of organic waste. Siqueira and Assad (2015) also highlight its importance in the return of nutrients to agroecosystems. The authors point out the need for identifying and characterizing different modalities of composting municipal solid waste (MSW), as an encouragement to create new technological routes and to diversify waste management systems in municipalities.

In 2018, the destination of 62.78 million tons of MSW collected in the country registered $74.35 \%$ for proper disposal (landfills), $23.97 \%$ for inadequate disposal (controlled landfills and dumps), $1.49 \%$ for selective collection, and only $0.19 \%$ for composting. This distribution indicates the insufficiency of public policies aimed at recovering the organic portion of MSW (SNIS, 2017).

Countries concerned with sustainability in MSW management have an efficient system of waste sorting. However, the lack of organic waste segregation at source is a major problem in developing countries, considering that organics are collected as common waste and sent for final disposal with household residues through the regular municipal collection. Therefore, avoidable expenses are generated, as the organic matter could be separated at the source and sent for specific treatment (IPEA, 2018), which is the case of composting.

The National Solid Waste Policy (PNRS) is Brazil's main regulatory framework for the sector and presents composting as an alternative to the final disposal of organic waste. Waste hierarchy involves the follow- ing procedures: non-generation of waste, reduction, reuse, recycling, solid waste treatment, and environmentally appropriate final disposal of waste. Thus, composting becomes an interesting option and it is prioritized as a way of treating organic waste. In addition to promoting the recovery of organic waste and valuing it, composting is configured as an environmentally appropriate destination that avoids waste disposal in the soil (BRASIL, 2010).

The application of the composting technique is directly linked to the strategies of waste prevention, waste reduction, smart cities, and zero waste program (EUROPEAN COMMISSION, 2016). In the current environmental context, citizens play a fundamental role in minimizing waste. Individuals should decide whether or not to separate one's waste and send it to the different and specific final destinations available and focused on its recovery.

In a study carried out in the city of São Paulo, Siqueira and Assad (2015) proposed to classify composting as centralized and decentralized, with the latter subdivided into institutional, home, and community composting. Decentralized composting is still underexplored in Brazil, but presents itself as an alternative through a simplified and low-cost process (social technology).

\section{Factors related to the practice of decentralized composting}

Decentralized composting has been increasingly accepted in urban centers and can take place directly on the ground following minimum criteria or with the use of specific equipment, called compost bin or composter, that can be either homemade or manufactured (domestic/ household composting). There are several models of composters on the market, from manual to automated, with or without the incorporation of earthworms or biological accelerators. It is believed that cost, operational simplicity, compatible size, aesthetics, and geometry are determining factors in the users' choice of the model (JAYAPRAKASH; LOHIT; ABHILASH, 2018).

Experience reports provided by several authors indicate that the use of the domestic composter demands dedication and knowledge of the technique for users' effective satisfaction and for the continuity of the process.

In a study carried out by Faverial and Sierra (2014), in which composters were tested by volunteers for 84 days, $32 \%$ of the participants reported difficulties in maintaining home composting due to the presence of vectors, foul odor, leachate generation, and lack of space in homes to suitably place the equipment. Most of the volunteers impacted by these factors have chosen to discontinue the use of the composter. Similar problems related to the use of composters in domestic environments have been reported in studies carried out by Bench et al. (2005), Smith and Jasim (2009), Lléo et al. (2013), Metcalfe et al. (2012), and Margaritis et al. (2018), which reinforce the need to take users' perception into account when designing equipment for composting. According to Catecati et al. (2018), such evaluations subsidize and impact decisions about the final product and influence the users' experience. Thus, the importance 
of linking composting to the concept of usability must be highlighted. This concept is used to define the ease with which people can employ a tool or object to perform a specific task (ISO, 1998).

To produce compact solutions suitable for environments with reduced space, it is essential to understand how the geometric model of the composter interferes with operational performance and usability. This aspect can improve the relationship between users and the equipment and enable the continuity of small-scale composting.

In this context, the purpose of this study was to optimize the physical characteristics of the composting bins for decentralized composting in residential and institutional environments considering the users' perception as a fundamental role to enhance the use of this sustainable practice.

\section{Method}

The research was developed in three methodological stages as illustrated in Figure 1. In the first stage (S1), the experimental apparatus, made of 5 composter prototypes, was developed. Then, in the second stage (S2), the developed models have been filled with residues and submitted to bench tests for 60 days to assess performance concerning sanitary aspects and the Normative Instruction of the Secretariat of Defense and Agriculture (SDA) of the Ministry of Agriculture, Livestock and Supply (MAPA) SDA/MAPA 25/2009(BRASIL, 2009). In the third stage (S3), the three models with the best performance were simultaneously filled up and operated by five users in a domestic environment for 50 days to assess the usability concept. In the end, an integrated analysis of results from stages S2 and S3 was carried out and discussion based on a bibliographic survey was performed.

The bench tests and analysis were carried out in the laboratories of the Federal Institute of Espírito Santo (Ifes) Campus Vitória, in the Research, Innovation and Development Center (CPID) of the State of Espírito Santo and in a specific laboratory specialized in the agronomic analysis.

\section{Development of the Experimental Apparatus (S1)}

As a result of the bibliographic review, handcrafted small-scale composters developed by 25 researchers were found, presenting different physical characteristics and the experimental design used in each study. Marketing research carried out in the first half of 2019 on websites of national and international manufacturers and resellers of domestic composters resulted in 42 models of different brands available and their respective physical characteristics. Tabulation and joint analysis of these results were the basis for the selection of five different geometries, used in the making of the experimental apparatus (the prototypes of the studied composters).

Prototypes were designed with a capacity of approximately 3 liters each, in order to maintain the scale with the use of the SolidWorks 2016 software version 9000 (SOLID WORKS, 2016). This capacity aimed to adequate studies on laboratory benches and facilitate the handling of prototypes. The prototypes were made with a $3-\mathrm{mm}$ thick transparent acrylic and each model received nine $4-\mathrm{mm}$ holes at the bottom for aeration and drain of any percolated liquid. A ruler was internally fixed to assist in the monitoring of the volume reduction of waste during the process, and a protection screen was installed at the top of the prototypes for insect protection. The experiment was carried out with five replicates for each of the five selected geometries, ending up in 25 geometric models (S2). The dimensions and layouts of the composter prototypes (experimental apparatus) are shown in Table 1 and Figure 2.

\section{Bench test (S2)}

To start the experiment, the composter prototypes were filled in batches using the same mixture of organic residues and prepared in order to obtain the ideal carbon/nitrogen ratio ( $\mathrm{C}: \mathrm{N}$ ratio) to start the process that, according to Kiehl (2004), is around 30:1. Proportions of residues were calculated by Equation 1, according to Massukado (2016), using the following equation for the calculation of the ideal C:N ratio (initial ratio of $30: 1$ ):

Ratio $\frac{C}{N}=\left(Q_{1} \times R C N_{1}+Q_{2} \times R C N_{2}+\cdots+Q_{n} \times R C N_{n}\right) /\left(Q_{1}+Q_{2}+Q_{n}\right)$

$Q=$ amount of waste by type;

$R C N=$ used C:N ratio of waste.

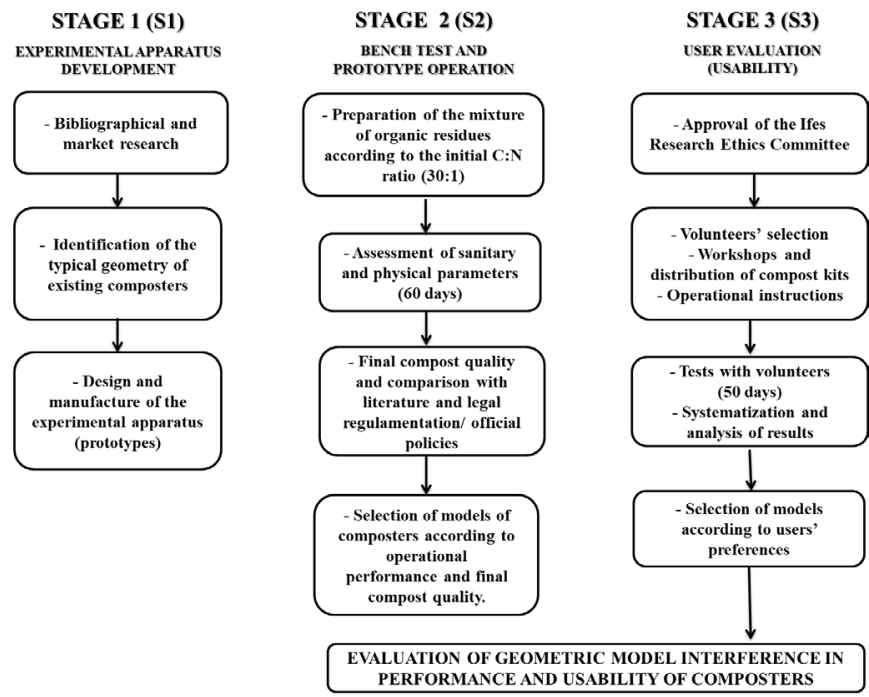

Figure 1 - Methodological stages.

Table 1 - Geometry and dimensions of the researched prototypes. Geometry Dimensions (m)

Cylinder $\left(\mathrm{P}_{1}\right) \quad 0.075$ (radius) $\times 0.170$ (height)

Hexagonal prism $\left(\mathrm{P}_{2}\right) \quad 0.080$ (base edge) $\times 0.150$ (height)

Triangular prism $\left(\mathrm{P}_{3}\right) \quad 0.180$ (base edge) $\times 0.180$ (height)

Cube $\left(\mathrm{P}_{4}\right)$

$0.144 \times 0.144 \times 0.144$ (edges)

Parallelepiped $\left(\mathrm{P}_{5}\right) \quad 0.170($ width $) \times 0.120($ depth $) \times 0.150$ (height $)$ 
The values of the C: $\mathrm{N}$ ratio used in the calculation are shown in Table 2.

The organic waste used in the experiment was collected in the restaurant of the institution that hosted the research. Dry leaves and yard trimmings were also collected in the institution. The residues were chopped, homogenized, and the used quantity and proportions are shown in Table 3. The preparation of the residues and the monitoring of the prototypes are illustrated in Figures 3 and 4, respectively.

As proposed by Arrigoni et al. (2018), the experiment was monitored three times a week with intervals of 48 to 72 hours. Sanitary aspects, such as the presence of vectors, leachate, foul odor, and mold, were monitored, as well as the internal and external temperature parameters, for which a thermo-hygrometer was used (Incoterm, model 7664 , accuracy of $1 \%$ for moisture and $1^{\circ} \mathrm{C}$ for temperature). A reduction in the volume of residues was also recorded during the decomposition process, and the amount of leachate was measured with the aid of a 50-mL graduated cylinder. As proposed by Guidoni et al. (2018), the resulting compost was analyzed according to the references found in the bibliographic search and the Normative Instruction 25/2009 (BRASIL, 2009) at the end of 60 days of carrying out the experiments.
Table 2 - C:N ratio of residues used to calculate the proportion of organic compounds used in the sample.

\begin{tabular}{|l|c|c|}
\hline Residues & C:N ratio & Reference \\
\hline Vegetables scraps & $25: 1$ & Planet Natural (2018) \\
\hline Fruit scraps & $35: 1$ & Planet Natural (2018) \\
\hline Sawdust & $132: 1$ & Carry on Composting (2019) \\
\hline Leaves & $40: 1$ & Microtack (2019) \\
\hline Grass & $25: 1$ & University of Missouri (2010) \\
\hline
\end{tabular}

Table 3 - Proportions of organic waste used in the experiment.

\begin{tabular}{|l|c|c|c|}
\hline Residues & $\begin{array}{c}\text { Total mass } \\
(\mathbf{k g})\end{array}$ & $\begin{array}{c}\text { Mass per } \\
\text { prototype }(\mathrm{g})\end{array}$ & $\begin{array}{c}\text { Distribution } \\
(\%)\end{array}$ \\
\hline Vegetable peelings & 3.850 & 154.270 & 51.42 \\
\hline Fruit waste & 1.710 & 68.580 & 22.86 \\
\hline Sawdust & 0.210 & 8.550 & 2.85 \\
\hline Dry Leaves & 0.428 & 17.130 & 5.71 \\
\hline Grass clippings & 1.280 & 51.420 & 17.14 \\
\hline Total & 7.500 & 300.000 & $\approx 100.00$
\end{tabular}
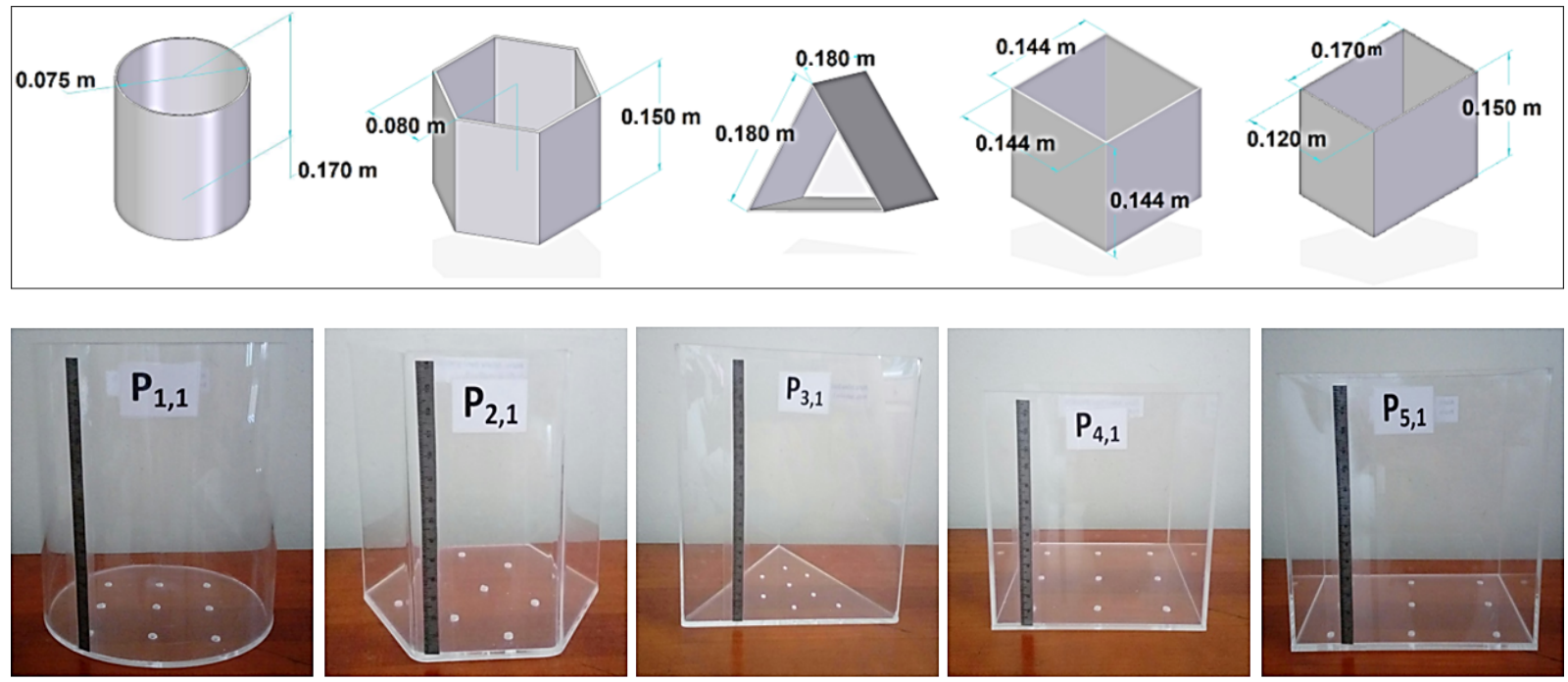

Figure 2 - Layout of the researched composter prototypes.
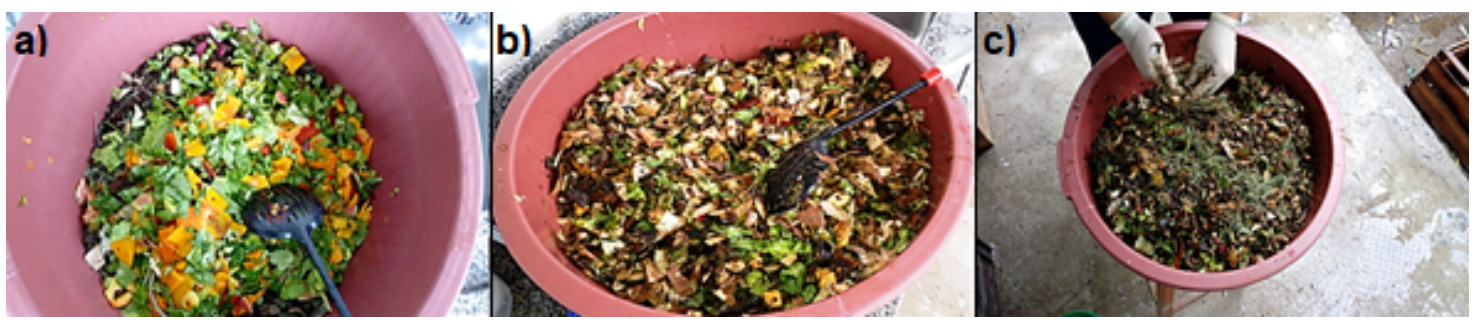

Figure 3 - Organic waste preparation for the assembly of experiments. (A) Chopped vegetables and fruits; (B) addition of crop residues (dry leaves and grass); (C) manual mixing of residues. 
The results of variables and parameters of the final organic compound were analyzed by statistical tests performed with the Statistical Data Analysis SPSS software, version 20 (IBM, 2016). The used experimental design was completely randomized, with five treatments and five repetitions (S2). Data were submitted to variance analysis and the treatment averages were compared using the Tukey's test at a $5 \%$ probability level. The parameters analyzed during S2 are shown in Table 4.

At the end of the second stage, the researchers selected the three geometric models that presented the best results according to the legal requirements for organic compost (BRASIL, 2009) and sanitary aspects observed during the monitoring.

\section{Users' evaluation (S3)}

To identify aspects that interfere in the daily and regular use of composters and consequently be able to propose improvements, five volunteers from the Ifes academic community (Campus Vitória), including students and employees, were selected and each of them received the three best performing models defined in S2. The three selected geometric models were tested in parallel by the five volunteers for 50 days, totaling 15 prototypes tested in the S3.

To determine factors related to the insertion of composting in the daily routine of ordinary people, the volunteers' selection process prioritized participants inserted in the labor market and without training in environmental subjects. The performance of this stage was approved by the Institutional Research Ethics Committee of Ifes. The profile of the selected volunteers is shown in Table 5.

Preparatory workshops were previously carried out to answer any necessary questions and provide a composting kit and guidelines re- garding the experiment to each volunteer. The delivered kit contained three geometric models of composter prototypes, monitoring sheets, standard dry organic waste (composed of earth and sawdust), water sprinkler, spoon, the base for collecting leachate, a protection net, rubber bands (against vectors), and a container for packing organic waste. The WhatsApp mobile application was used throughout this stage to support the volunteers in solving any necessary issue and providing information to researchers such as monitoring tables and photographic records. The kit delivered to each participant and the workshop are illustrated in Figure 5.

\section{Results}

Selection of geometry based on bibliographic studies and marketing research

The results of the bibliographic studies and marketing research enabled to identify the main geometric models that were being used in the design of homemade and industrial composters (Table 6).

Geometric models with a rectangular and cylindrical base were selected for the study because they were more common in both bibliographic and marketing research. On the other hand, the hexagonal model was chosen for tests due to the notoriety obtained in the marketing research. Composters with trapezoidal and spherical geometry were also identified in the survey; however, due to budget constraints, they were not tested.

Considering that five different models would be tested, the cube (square base) and the triangular prism were added to the previously three selected models, as the former results in a more compact equipment and the latter enables the modulation of equipment (fitting more than one composting unit in parallel), making it flexible to meet different types of environments.

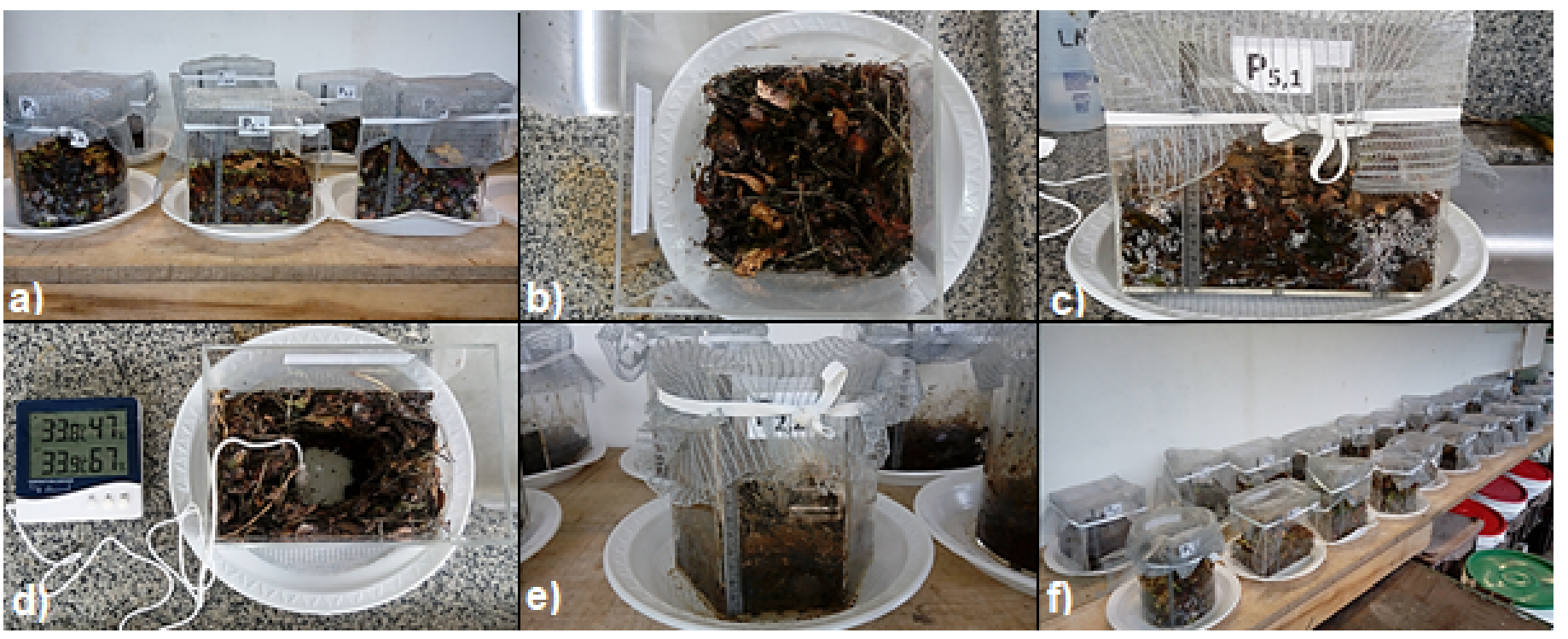

Figure 4 - Laboratory bench test monitoring. (A and F) View of the experiment installed on a laboratory bench; (B) internal view of the prototype in operation; (C and E) front view of prototypes and detail of the sanitary control screen; (D) monitoring of moisture and temperature using a thermo-hygrometer. 
Table 4 - Parameters analyzed in stage 2 (S2) of the experiment.

\begin{tabular}{|c|c|c|}
\hline Period & Parameters & Analysis methodology \\
\hline \multirow{6}{*}{$\begin{array}{l}\text { Starting the } \\
\text { experiment } \\
\left(\mathrm{T}_{0}\right)\end{array}$} & Mass & $\begin{array}{c}\text { Scale (model SF } 400,10 \\
\text { kg capacity) }\end{array}$ \\
\hline & Volume & Level measurement \\
\hline & $\begin{array}{c}\text { External (environment) } \\
\text { and internal (prototypes) } \\
\text { temperature and } \\
\text { moisture }\end{array}$ & Thermo-hygrometer \\
\hline & $\mathrm{pH}$ & Standard Methods \\
\hline & Conductivity & (APHA, 1998) \\
\hline & $\begin{array}{c}\text { moisture } \\
\text { Total, Fixed, and Volatile } \\
\text { Solids }\end{array}$ & $\begin{array}{c}\text { Gravimetric analysis } \\
\text { (NBR 10664/1989) } \\
\text { (ABNT, 1989) }\end{array}$ \\
\hline \multirow[b]{3}{*}{$\begin{array}{l}\text { Monitoring ( } 3 \\
\text { times a week) }\end{array}$} & Volume & Level measurement \\
\hline & Sanitary aspects & Observation \\
\hline & $\begin{array}{c}\text { External (environment) } \\
\text { and internal (prototypes) } \\
\text { temperature and } \\
\text { moisture }\end{array}$ & Thermo-hygrometer \\
\hline \multirow{11}{*}{$\begin{array}{l}60 \text { days }\left(\mathrm{T}_{60}\right)- \\
\text { Compost }\end{array}$} & Mass & Scale \\
\hline & Volume & Level measurement \\
\hline & Sanitary aspects & Observation \\
\hline & $\begin{array}{c}\text { External (environment) } \\
\text { and internal (prototypes) } \\
\text { temperature and } \\
\text { moisture }\end{array}$ & Thermo-hygrometer \\
\hline & $\mathrm{pH}$ & \multirow{2}{*}{$\begin{array}{l}\text { Standard Methods } \\
\text { (APHA, 1998) }\end{array}$} \\
\hline & Conductivity & \\
\hline & $\begin{array}{l}\text { Amount of organic } \\
\text { carbon }\end{array}$ & \multirow{3}{*}{$\begin{array}{c}\text { Handbook Manual } \\
\text { de Métodos Analíticos } \\
\text { oficiais para Fertilizantes } \\
\text { e Corretivos (BRASIL, } \\
\text { 2017) }\end{array}$} \\
\hline & Total of nitrogen & \\
\hline & C:N ratio & \\
\hline & Moisture (compost) & \multirow{2}{*}{$\begin{array}{c}\text { Gravimetric analysis } \\
\text { (NBR 10664/1989) } \\
\text { (ABNT, 1989) }\end{array}$} \\
\hline & $\begin{array}{l}\text { Total, Fixed, and Volatile } \\
\text { Solids }\end{array}$ & \\
\hline
\end{tabular}

\section{Bench test stage (S2)}

In stage 2 , the five geometric models had their performance tested and evaluated considering the final compost achieved by each model and its sanitary and operational aspects.

The initial mass of organic waste (300 g), equally added to all prototypes, was reduced due to degradation and transformation into organic compost, which resulted in the final average mass values of compost presented in Table 7.

According to the results, the $\mathrm{P} 3$ model (triangular prism) presented the lowest amount of final mass, reaching the highest mass reduction (84.54\%), whereas the P5 model (parallelepiped) had the lowest mass reduction (78.58\%). According to Onwosi et al. (2017), the reduction in mass is related to the decrease in moisture content and the decomposition of organic matter.

At the end of the bench tests (S2), samples of compost (50.0 g) obtained from each prototype model were sent to a laboratory specialized in agronomic quality tests (organic carbon, total nitrogen, and C:N ratio). The results indicated satisfactory agronomic characteristics, according to Brazilian regulations (BRASIL, 2009), for all geometric models.

Regarding the $\mathrm{pH}$ of the final compost, most geometric models presented a basic character (variation from 8.2 to 9.9), which behavior is similar to the one observed by Guidoni et al. (2018) and Tatàno et al. (2015), who obtained results between 8.0 to 10.0, also following the Normative Instruction SDA/MAPA 25/2009 (BRASIL, 2009).

Concerning moisture levels, all 25 prototypes produced organic compost in compliance with the Normative Instruction SDA/MAPA 25/2009 standard (maximum of 50\%) (BRASIL, 2009). The initial moisture of the organic mass was $71 \%$, but it decreased over the 60 days of the experiment, resulting in final compost values that ranged from $12 \%$ to $15 \%$.

The electrical conductivity ranged from 0.43 to $0.71 \mathrm{mS} / \mathrm{cm}$ at $25^{\circ} \mathrm{C}$, which were lower numbers when compared with those found by Arrigoni et al. (2018) (from 2 to $5 \mathrm{mS} / \mathrm{cm}$ ), Tatàno et al. (2015) (from 2 to $5 \mathrm{mS} / \mathrm{cm})$, and Lléo et al. (2013) $\left(1.9 \pm 0.2 \mathrm{mS} / \mathrm{cm}\right.$ at $\left.25^{\circ} \mathrm{C}\right)$. This

Table 5 - Profile of volunteers for the usability test of composter models.

\begin{tabular}{|c|c|c|c|c|c|}
\hline \multirow{2}{*}{ Participant Profile } & \multicolumn{5}{|c|}{ Volunteers } \\
\hline & V1 & V2 & V3 & V4 & V5 \\
\hline Age (years) & 29 & 25 & 38 & 57 & 28 \\
\hline Major in & Engineering & Engineering & Engineering & Physics & Chemistry \\
\hline Currently working? & No & No & Yes & Yes & Yes \\
\hline Type of residence & Apartment & Apartment & House & Apartment & House \\
\hline Individual eating routine & Restaurant & At home & At home & Restaurant & At home \\
\hline Family eating routine & At home & At home & At home & Restaurant & At home \\
\hline Previous experience with composting & No & No & No & Yes & No \\
\hline
\end{tabular}


difference in results can be justified due to differences in the composition of the standard waste used in the prototypes and variations in the methodologies used in the studies.

Regarding the minimum value of $15 \%$ organic carbon in the final compound required by the Normative Instruction, all geometries and prototypes complied with such regulation (31.18 to $41.18 \%$ ). The obtained values were similar to the ones observed by Tatàno et al. (2015), which ranged from 28 to $38 \%$.

The results also showed that all tested models achieved the minimum value of nitrogen established in the Normative Instruction $(0.5 \%)$, with results ranging between 2.14 and $2.77 \%$, but did not reach the same numbers of Tatàno et al. (2015), who obtained values ranging from 2 to $4 \%$. The difference can be due to the initial composition of residues and the room temperature of each location in the studies, which were not the same.

The final C:N ratio values were within expectations, with a variation between $1 / 14$ and $1 / 16$ under the maximum of $1 / 20$ established by the Normative Instruction. Tatàno et al. (2015) obtained values of C:N ratio ranging between $5 / 1$ and $15 / 1$, which were close to results obtained in the present research even with considerable variation. Kumar et al. (2009) considered the 10: 1 and 15: 1 range to be ideal.

The physicochemical parameters analyzed in the compost were subjected to variance analysis and the means were compared by the Tukey's test at a 5\% probability level. The results are shown in Table 8.

Performance analysis of the different prototype models pointed out significant statistical differences between them regarding the parameters of conductivity, organic carbon, total nitrogen, fixed and volatile solids, and C:N ratio.

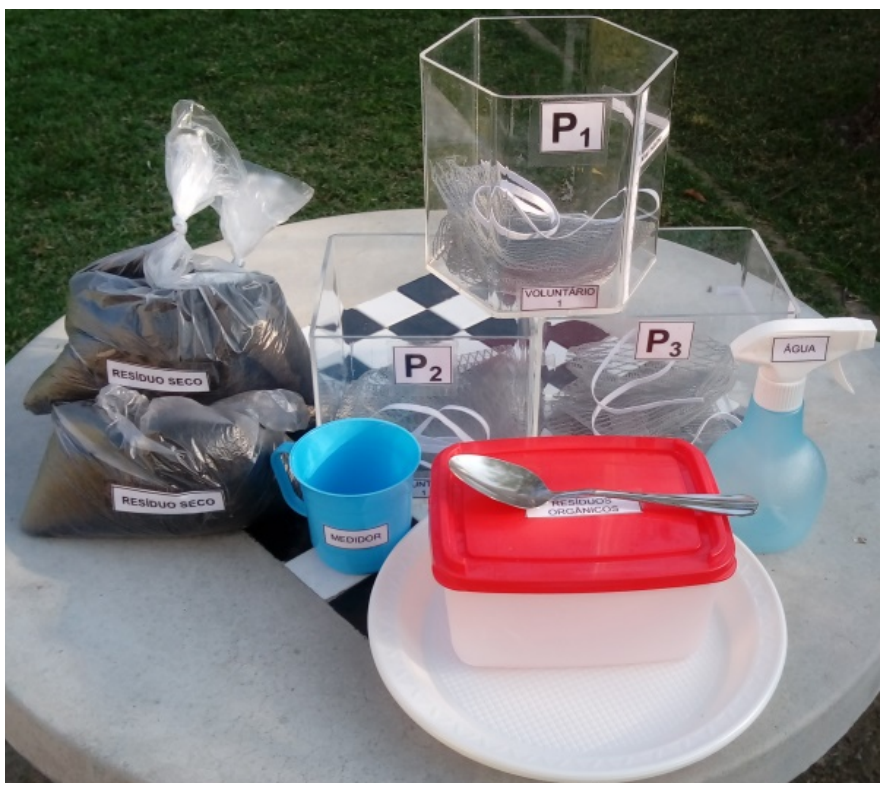

Table 6 - Common geometric models identified by the type of search source and frequency.

\begin{tabular}{|c|c|}
\hline Type of search source & Common geometric models identified \\
\hline Bibliographic search & $\begin{array}{c}1^{\text {st: }} \text { Cylindrical } \\
2^{\text {nd. }} \text { Rectangular } \\
3^{\text {rd. }} \text { Trapezoidal } \\
4^{\text {th. }} \text { Others* }\end{array}$ \\
\hline Marketing research & $\begin{array}{c}1^{\text {st: }} \text { Rectangular } \\
2^{\text {nd }}: \text { Cylindrical } \\
3^{\text {rd }}: \text { Hexagonal } \\
4^{\text {th }}: \text { Trapezoidal } \\
5^{\text {th }}: \text { Spherical }\end{array}$ \\
\hline
\end{tabular}

${ }^{*}$ Bags, baskets, plastic, 20-liter bottle or small windrows.

Table 7 - Organic mass variation in bench test stage according to prototype.

\begin{tabular}{|c|c|c|c|}
\hline Prototype & $\begin{array}{c}\text { Initial mass } \\
(\mathrm{g})\end{array}$ & $\begin{array}{c}\text { Average final } \\
\text { mass (g) }\end{array}$ & $\begin{array}{c}\text { Mass } \\
\text { reduction (\%) }\end{array}$ \\
\hline $\mathrm{P}_{1}$ & & 61.13 & 79.26 \\
\hline $\mathrm{P}_{2}$ & & 53.14 & 82.28 \\
\hline $\mathrm{P}_{3}$ & 300.00 & 46.36 & 84.54 \\
\hline $\mathrm{P}_{4}$ & & 63.85 & 78.71 \\
\hline $\mathrm{P}_{5}$ & & 64.26 & 78.58 \\
\hline
\end{tabular}

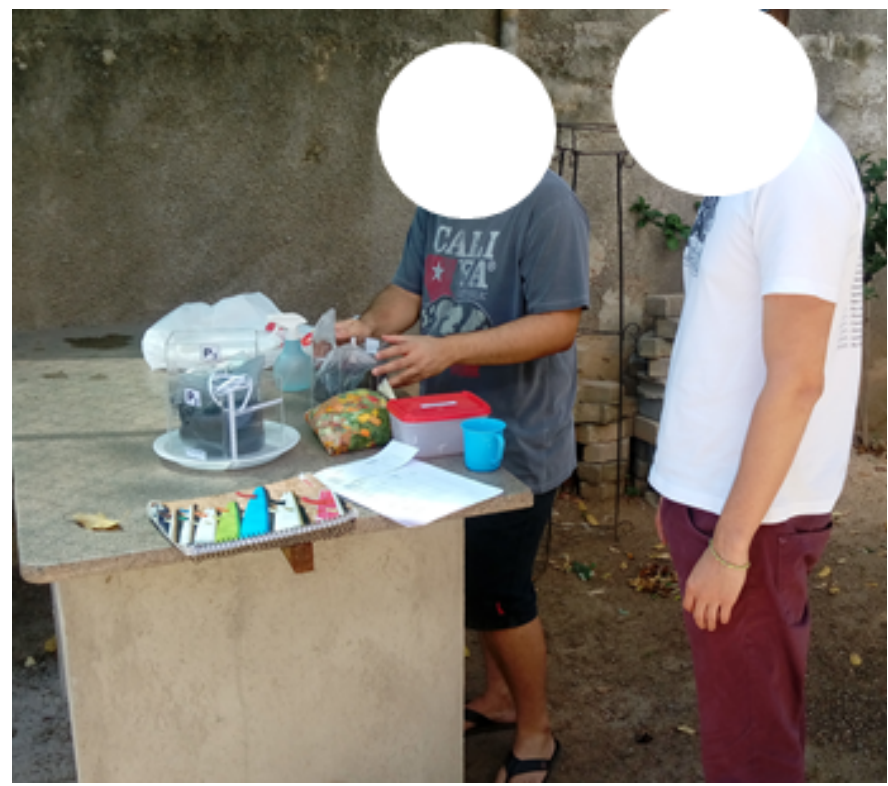

Figure 5 - (A) Composting kit delivered to volunteers and (B) preparatory workshop. 
The sanitary parameters and the ease of turning the compost were also analyzed, and the results are shown in Table 9.

Turning the compost was considered difficult in the prototypes which parts of organic waste fall out during the process, and easy when performed without difficulty and loss of compost. Prototype P3 (triangular prism) was considered difficult for turning the compost due to the geometry of its base, which has reduced space available for the movement.

Sanitary aspects registered with "yes" indicate the frequent and uncomfortable presence of leachate, vectors, and foul odor, whereas aspects marked with "no" correspond to the sporadic presence or absence of them. The P1 and P3 geometric models were not approved in relation to the sanitary aspects evaluated, as they resulted in the occurrence of leachate, presence of vectors, and foul smell during the operation period.

\section{Selection of geometric models for testing with volunteers}

The process of selecting the models for users' evaluation on usability has also considered the performed marketing research (S1). Although the most common geometries found in the market were rectangular, cylindrical, and hexagonal, it was decided to replace the cylindrical model with the cube, since the cylindrical prototype presented great difficulty to be handled with and negative occurrences regarding the sanitary aspects during the monitoring process. Thus, the prototype models P2 (hexagonal prism), P4 (cube), and P5 (par- allelepiped) were chosen. They have also obtained the best results in sanitary aspects, turning process, and agronomic characteristics. The models statistically differ from each other concerning parameters of conductivity, organic carbon, and total nitrogen (Table 8).

\section{Usability test with volunteers (S3)}

According to Catecati et al. (2018), the best way to test the functionality and usability of a product, prototype, or system is by subjecting it to user testing, in which daily practice brings results to identify possible difficulties in use and operational behavior. The authors also recommend that volunteers be encouraged to propose improvements to the tested equipment.

The volunteers' perceptions regarding the tested prototypes were collected through a structured questionnaire, applied at the end of the test (after 50 days). The questions were based on studies conducted by Faverial and Sierra (2014) and Bringhenti et al. (2015). The aspects evaluated on the practice of composting and user testing with prototype models are shown in Table 10.

Two volunteers with previous experience (V3 and V4) required less time for assembling and monitoring the composters. They also registered fewer negative occurrences during the experiment. However, regardless of previous experience, all five volunteers had difficulties in adjusting the moisture level of the waste mixture.

Table 8 - Results of statistical analysis for the averages of the analyzed parameters, according to prototype model ${ }^{1}$.

\begin{tabular}{|c|c|c|c|c|c|c|}
\hline \multirow[b]{2}{*}{ Prototype Model } & \multicolumn{5}{|c|}{ Parameters } & \multirow[b]{2}{*}{ Volatile Solids } \\
\hline & $\begin{array}{l}\text { Electrical } \\
\text { conductivity }\end{array}$ & $\begin{array}{l}\text { Organic } \\
\text { Carbon }\end{array}$ & Total Nitrogen & $\begin{array}{l}\mathrm{C}: \mathrm{N} \\
\text { ratio }\end{array}$ & Fixed Solids & \\
\hline$P_{1}$ & $0.5526 \mathrm{a}$ & $39.4260 \mathrm{a}$ & $2.6020 \mathrm{a}$ & $15 / 1 \mathrm{ab}$ & $21.1272 \mathrm{ab}$ & $78.8728 \mathrm{ab}$ \\
\hline $\mathrm{P}_{2}$ & $0.6178 \mathrm{ab}$ & $39.0560 \mathrm{a}$ & $2.6640 \mathrm{a}$ & $14 / 1 \mathrm{bc}$ & $18.6634 \mathrm{~b}$ & $81.3366 \mathrm{a}$ \\
\hline $\mathrm{P}_{3}$ & $0.6256 \mathrm{ab}$ & $38.2360 \mathrm{a}$ & $2.4460 \mathrm{~b}$ & $15 / 1$ a & $23.1784 \mathrm{a}$ & $76.8216 b$ \\
\hline $\mathrm{P}_{4}$ & $0.4536 \mathrm{c}$ & $32.2000 \mathrm{~b}$ & $2.2634 \mathrm{c}$ & $14 / 1 \mathrm{c}$ & $19.0610 \mathrm{~b}$ & $80.9390 \mathrm{a}$ \\
\hline $\mathrm{P}_{5}$ & $0.6564 \mathrm{a}$ & $32.0020 \mathrm{~b}$ & $2.2200 \mathrm{c}$ & $14 / 1 \mathrm{c}$ & $19.9572 \mathrm{ab}$ & $80.0428 \mathrm{ab}$ \\
\hline $\begin{array}{l}\text { Reference values Normative } \\
\text { Instruction SDA/MAPA 25/2009 }\end{array}$ & * & $\min .0 .50$ & * & $\max .20 / 1$ & * & * \\
\hline
\end{tabular}

${ }^{1}$ The averages followed by distinct letters statistically differ according to the Tukey's test at a 5\% probability level; P1: cylinder; P2: hexagonal prism; P3: triangular prism; P4: cube; P5: parallelepiped; ${ }^{\star}$ there are no reference values for these parameters in the Normative Instruction SDA/MAPA 25/2009 (BRASIL, 2009).

Table 9 - Sanitary aspects and ease of turning according to each prototype.

$\begin{array}{ccccccc}\text { Stage } & \text { Prototype Model } & \text { Turning compost } & \text { Presence of leachate? } & \text { Presence of vectors? } & \text { Presence of foul odor? } \\ & \mathrm{P}_{1} & \text { Easy } & \text { Yes } & \text { Yes } & \text { No } & \text { No } \\ \text { Stage } 2 & \mathrm{P}_{2} & \text { Easy } & \text { Yes } & \text { Yes } & \text { Yes } \\ & \mathrm{P}_{3} & \text { Difficult } & \text { Yes } & \text { No } & \text { No } \\ & \mathrm{P}_{4} & \text { Easy } & \text { No } & \text { No } & \text { No }\end{array}$

P1: cylinder; P2: hexagonal prism; P3: triangular prism; P4: cube; P5: parallelepiped. 
Due to difficulties in adapting the use of prototypes in daily routines, it was observed that the employed volunteers decided to operate the composters at the weekends, which indicates an adaptive practice.

Results with volunteers in a research conducted by Faverial and Sierra (2014) indicated that $68 \%$ of the participants did not report any difficulties in the practice of composter operation in a domestic environment and that the main difficulties encountered were: presence of vectors, odor, and leachate; and difficulty in finding an adequate and safe place to implant (or store) the composter. Such findings are similar to those found in the present study.

Concerning the usability aspect, the hexagonal prism and cube models were preferred. The preference for the models was attributed to the ease of adding residues and turning the compost, in addition to the more ergonomic design presented by both of them.

Although the rectangular-based model (parallelepiped) promoted greater reduction in volume and degradability of organics, the usability was not approved by four $(80 \%)$ of the five volunteers, due to the difficulty in use. Although this geometry was more frequent in the marketing research and the second most common in the bibliographic search, it was not approved by the users, which reinforc- es the importance of considering the human factor in the design of composting equipment.

The results concerning the users' evaluation of the prototype models were compared with the literature, as demonstrated in Table 11.

It is worth mentioning the lack of studies on usability for these kinds of equipment to provide a broader comparison with the obtained results, especially concerning the approaches to make the equipment used in decentralized composting more efficient and effective.

\section{Projects adapted from domestic composters}

With the aid of the SolidWorks 2016 software version 9000, and by adding the improvements proposed by the volunteers to the best rated models of composters in the research (hexagonal prism and cube), two conceptual models of composters were projected for better usability. The projected designs are shown in Figure 6.

\section{Conclusions}

It was statistically found that the geometry of the composter influenced the characteristics of the compost in terms of organic carbon parameters, total nitrogen, $\mathrm{C}: \mathrm{N}$ ratio, fixed and volatile solids and, consequently, its agronomic quality.

Table 10 - Aspects evaluated by volunteers in the test with composter prototypes.

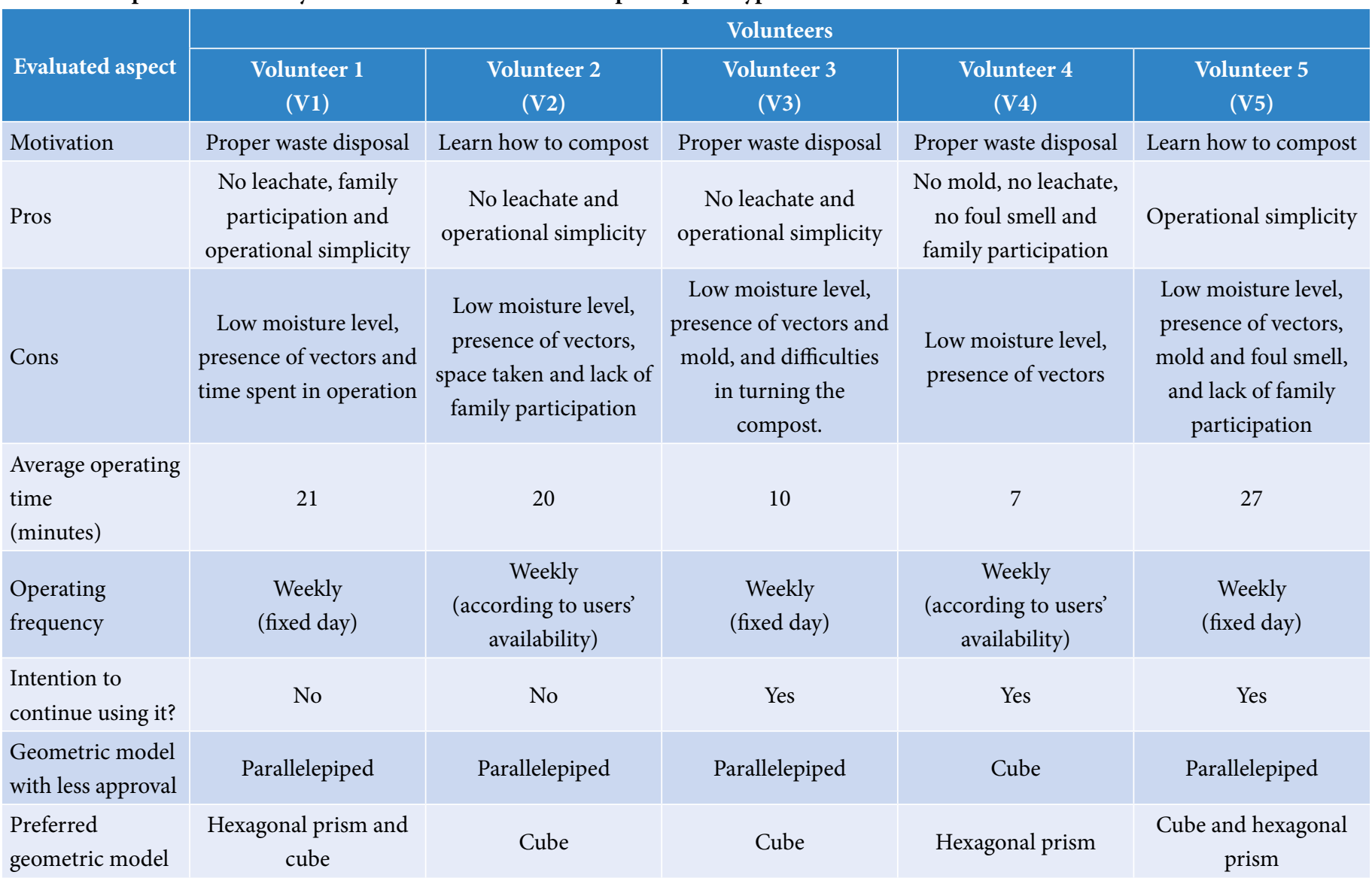


Table 11 - Factors related to the use of composters in domestic environments, according to the literature and the test performed with users.

\begin{tabular}{|c|c|c|}
\hline Factor & Literature review ${ }^{\star}$ & Users' feedback \\
\hline Waste management & $\begin{array}{l}\text { - Layout interference in the composter filling and } \\
\text { compost removal. }\end{array}$ & - Removable bottom to remove compost. \\
\hline Operational capacity & $\begin{array}{l}\text { - Appropriate dimensions to existing space. } \\
\text { - Adequate capacity to local organic waste production } \\
\text { and frequency of use (daily, weekly, etc.). }\end{array}$ & - Insufficient capacity to the organic waste generated \\
\hline $\begin{array}{l}\text { Aesthetics and } \\
\text { ergonomics }\end{array}$ & $\begin{array}{l}\text { - Be visually attractive and encourage use. } \\
\text { - Contain visual instructions on how to use. }\end{array}$ & $\begin{array}{l}\text { - Round edges for better accommodation and turning of } \\
\text { waste. }\end{array}$ \\
\hline $\begin{array}{l}\text { Operational } \\
\text { requirements }\end{array}$ & $\begin{array}{l}\text { - To provide simplified usage procedures and be } \\
\text { accessible to different kinds of users. }\end{array}$ & - Flexibility in operation frequency. \\
\hline Cost & - Compatible with used material and technology. & - Use of resistant and sustainable material (recycled). \\
\hline
\end{tabular}

*Based on Jayaprakash, Lohit and Abhilash (2018) and Metcalfe et al. (2012).

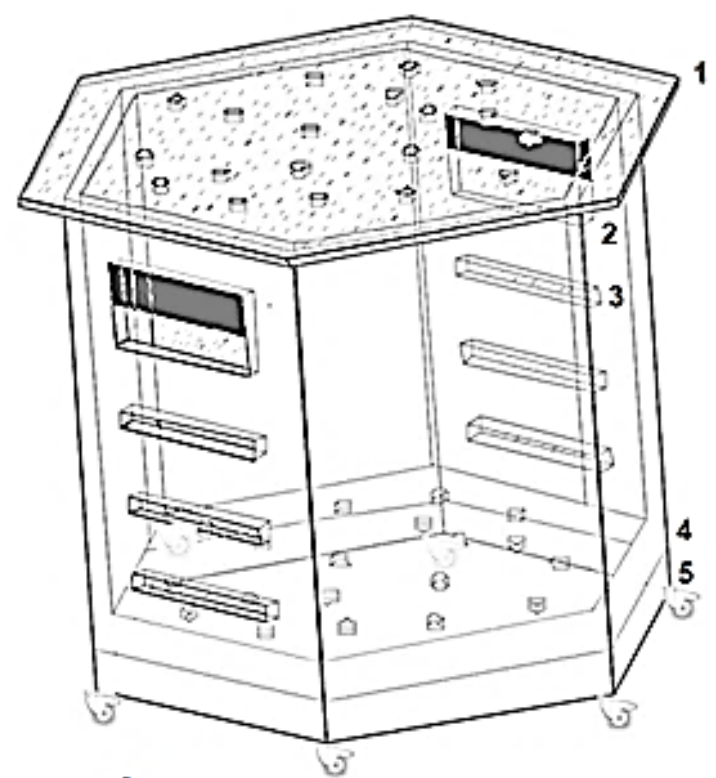

a)

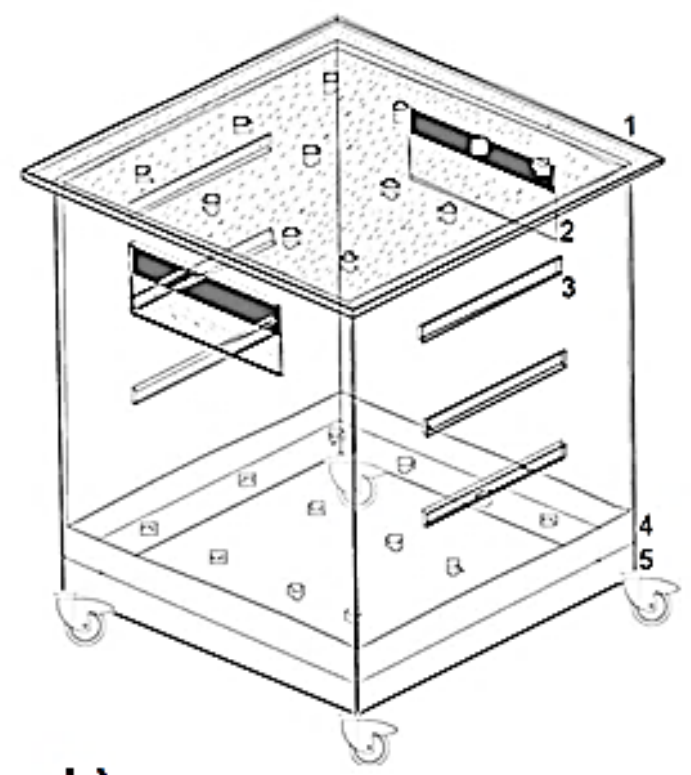

b)

Figure 6 - Illustrative scheme of small-scale composter prototypes. (A) hexagonal prism; (B) cube; dimensions of $0.25 \mathrm{~m} \times 0.25 \mathrm{~m} \times 0.25 \mathrm{~m}$, approximately totaling $15 \mathrm{~L}$.

1: Perforated and screened removable cover; 2: handles; 3: screened ventilation opening; 4: removable bottom for collecting leachate; 5: removable bottom for final compost removal. 
The practice of composting and the daily operation by volunteers led to a preference for two geometric composter models: hexagonal prism and cube. Ergonomics, ease of use, and facility for turning composting were decisive factors in this choice. It can be seen, therefore, that geometry influenced the usability of the tested prototypes.

The improvements proposed by users contributed to the design of easier-to-use models, which may contribute to the dissemination of the small-scale composting technique and the continuity of household practice or in similar environments, which are aspects of waste minimization and sustainability.

\section{Acknowledgements}

The authors would like to gratefully thank Ifes for the financial support for translating the article.

\section{Contribution of authors:}

Dazzi, J.G.: Conceptualization, Data curation, Formal analysis, Funding, acquisition, Investigation, Methodology, Validation, Visualization, Writing - original draft, Writing - review \& editing. Pires, P.D.Z.: Data curation, Formal analysis, Methodology, Validation, Writing - review \& editing. Korres, A.M.N.: Conceptualization, Methodology, Resources, Writing - review \& editing. Günther, W.M.R.: Methodology, Writing - review \& editing. Dadalto, F.S.: Data curation, Formal analysis, Acquisition, Investigation. Bringhenti, J.R.: Conceptualization, Data curation, Formal analysis, Funding, acquisition, Investigation, Methodology, Resources, Supervision, Validation, Visualization, Writing - original draft, Writing - review \& editing.

\section{References}

AMERICAN PUBLIC HEALTH ASSOCIATION (APHA). Standard methods for the examination of water and wastewater. 20. ed. Washington, D.C.: American Public Health Association, American Water Works Association, Water Environmental Federation, 1998.

ARRIGONI, J. P.; PALADINO, G.; GARIBALDI, L. A.; LAOS, F. Inside the small-scale composting of kitchen and garden wastes: Thermal performance and stratification effect in vertical compost bins. Waste Management, v. 76, p. 284-293, 2018. https://doi.org/10.1016/j.wasman.2018.03.010

ASSOCIAÇÃO BRASILEIRA DE NORMAS TÉCNICAS (ABNT). NBR 10664: águas - determinação de resíduos sólidos pelo método gravimétrico. Rio de Janeiro: ABNT, 1989.

BENCH, M. L.; WOODARD, R.; HARDER, M. K.; STANTZOS, N. Waste minimization: home digestion of biodegradable waste. Resources, Conservation and Recycling, v. 45, n. 1, p. 84-94, 2005. https://doi.org/10.1016/j. resconrec.2005.02.003

BRASIL. Ministério da Agricultura, Pecuária e Abastecimento. Instrução Normativa SDA/MAPA 25/2009. Diário Oficial da União, Brasília, 2009.

BRASIL. Ministério da Agricultura, Pecuária e Abastecimento. Manual de métodos analíticos oficiais para fertilizantes e corretivos. Brasília: Ministério da Agricultura, Pecuária e Abastecimento, 2017. Available at: <https://www. gov.br/agricultura/pt-br/assuntos/insumos-agropecuarios/insumos-agricolas/ fertilizantes/legislacao/manual-de-metodos_2017_isbn-978-85-7991-109-5. pdf>. Accessed on: Aug 26, 2020.

BRASIL. Ministério do Meio Ambiente. Lei no 12.305 de 2 de agosto de 2010. Institui a Política Nacional de Resíduos Sólidos. Diário Oficial da União, Brasília, 2010

BRINGHENTI, J. R.; CAMPOS, J. S.; TONINI, E. V.; KORRES, A. M. N. A compostagem em pequena escala como alternativa de minimização de resíduos sólidos em domicílios. In: Congresso Brasileiro de Engenharia Sanitária e Ambiental, 28., 2015, Rio de Janeiro. Annals [...]. 2015.

CARRY ON COMPOSTING. Home and community composting. Carry on Composting, 2019. Available at: <http://www.carryoncomposting. com/416920203>. Accessed on: Mar 3, 2020.
CATECATI, T.; FAUST, F. G.; ROEPKE, G. A. L.; ARAUJO, F. S.; ALBERTAZZI, D.; RAMIREZ, A. R. G.; FERREIRA, M. G. G. Métodos para avaliação da usabilidade no design de produtos. DAPesquisa, v. 6, n. 8, p. 564581, 2018. https://doi.org/10.5965/1808312906082011564

DUTRA, A. C.; MEDEIROS, G. A.; GIANELLI, B. F. Avaliação do ciclo de vida como uma ferramenta de análise de impactos ambientais e conceito aplicados em programas educativos. Revista Brasileira de Ciências Ambientais, n. 51, p. 15-27, 2019. https://doi.org/10.5327/Z2176-947820190399

EUROPEAN COMMISSION. Waste prevention. European Commission, 2016. Available at: $<$ http://ec.europa.eu/environment/waste/prevention/index.htm $>$. Accessed on: Jul 9, 2018

FAVERIAL, J.; SIERRA, J. Home composting of household biodegradable wastes under the tropical conditions of Guadeloupe (French Antilles). Journal of Cleaner Production, n. 83, p. 238-244, 2014. https://doi.org/10.1016/j. jclepro.2014.07.068

FEIL, A.; SPILKI, F.; SCHREIBER, D. Global analysis of the characteristics of urban residential waste fractions. Revista Brasileira de Ciências Ambientais, $\mathrm{n}$. 38, p. 63-77, 2015. https://doi.org/10.5327/Z2176-9478201510914

GUIDONI, L. L. C.; MARQUES, R. V.; MONCKS, R. B.; BOTELHO, F. T.; PAZ, M. F.; CORRÊA, L. B.; CORRÊA, E. K. Home composting using different ratios of bulking agent to food waste. Journal of Environmental Management, $\mathrm{v}$. 207, p. 141-150, 2018. https://doi.org/10.1016/j.jenvman.2017.11.031

GÜNTHER, W. M. R. Poluição do solo. In: PHILIPPI JR., A.; PELICIONI, M. C. F. (org.). Educação ambiental e sustentabilidade. Barueri: Manole, 2005. p. 195-215.

IBM. SPSS Statistics 20. Statistics software. 20 version. Dassault Systemes. IBM, 2016.

INSTITUTO DE PESQUISA ECONÔMICA APLICADA (IPEA). Caderno de Diagnóstico: Resíduos Sólidos Urbanos. Brasília: IPEA, 2018. Available at: <http://www.snis.gov.br/downloads/diagnosticos/rs/2018/Diagnostico_ RS2018.pdf $>$. Accessed on: Mar 2020.

INTERNATIONAL ORGANIZATION FOR STANDARDIZATION (ISO). Ergonomics of human-system interaction - Part 11: Usability: 
Definitions and concepts. ISO, 1998. Available at: $<$ https://www.iso.org/obp/ ui/\#iso:std:iso:9241:-11:ed-2:v1:en>. Accessed on: Jun. 10, 2018.

JAYAPRAKASH, S.; LOHIT, H.S.; ABHILASH, B.S. Design and development of compost bin for Indian kitchen. International Journal of Waste Resources, $\mathrm{v}$. 8, n. 1, 2018. https://doi.org/10.4172/2252-5211.1000323

KIEHL, E. J. Manual de Compostagem: maturação e qualidade do composto. 4. ed. Piracicaba: E. J. Kiehl, 2004.

KUMAR, S.; KUMAR, M.; THUROW, K.; STOLL, R.; KRAGL, U. Fuzzy filtering for robust bio concentration factor modeling. Environmental Modelling \& Software, v. 24, n. 1, p. 44-53, 2009. https://doi.org/10.1016/j. envsoft.2008.05.002

LLÉO, T.; ALBACETE, E.; BARRENA, R.; FONT, X.; ARTOLA, A.; SÁNCHEZ, A. Home and vermicomposting as sustainable options for bio waste management. Journal of Cleaner Production, v. 47, p. 70-76, 2013. https:// doi.org/10.1016/j.jclepro.2012.08.011

MARGARITIS, M.; PSARRAS, K.; PANARETOU, V.; THANOS, A.G.; MALAMIS, D.; SOTIROPOULOS, A. Improvement of home composting process of food waste using different minerals. Waste Management, v. 73, p. 87-100, 2018. https://doi.org/10.1016/j.wasman.2017.12.009

MASSUKADO, L. M. Compostagem: nada se cria, nada se perde, tudo se transforma. Brasília: Instituto Federal de Brasília, 2016.

METCALFE, A.; RILEY, M.; BARR, S.; TUDOR, T.; ROBINSON, G.; GUILBERT, S. Food waste bins: bridging infrastructures and practices. The Sociological Review, v. 60, n. S2, p. 135-155, 2012. https://doi.org/10.1111/1467-954X.12042

MICROTACK. Carbon/nitrogen ratio for various compostable materials. Microtack, 2019. Available at: <https://www.microtack.com/html/compost_ carbon.html>. Accessed on: Mar 3, 2020.

ONWOSI, C. O.; IGBOKWE, V. C.; ODIMBA, J. N.; EKE, I. E.; NWANKWOALA, M. O.; IROH, I. N.; EZEOGU, L. I. Composting technology in waste stabilization: On the methods challenges and future prospects. Journal of Environmental Management, v. 190, p. 140-157, 2017.

ORGANIZAÇÃO DAS NAÇÕES UNIDAS (ONU). Transformando o nosso mundo: a agenda 2030 para o desenvolvimento sustentável. ONU, 2015. Available at: $<$ https://nacoesunidas.org/pos2015/agenda2030/ $>$. Accessed on: Jan 2, 2020.

PLANET NATURAL. Planet Natural Research Center. Carbon-to-Nitrogen Ratios. Planet Natural, 2018. Available at: <https://www.planetnatural.com/ composting-101/making/c-n-ratio/>. Accessed on: Mar 3, 2020.

SIQUEIRA, T. M. O.; ASSAD, M. L. R. C. L. Compostagem de resíduos sólidos urbanos no estado de São Paulo (Brasil). Ambiente \& Sociedade, v. 18, n. 4, p. 243-264, 2015. https://doi.org/10.1590/1809-4422ASOC1243V1842015

SISTEMA NACIONAL DE INFORMAÇÕES SOBRE SANEAMENTO (SNIS). Diagnóstico do manejo de resíduos sólidos urbanos. Brasília: Ministério das Cidades, Secretaria Nacional de Saneamento Ambiental, 2017. Available at: $<$ http://www.snis.gov.br/diagnostico-residuos-solidos/diagnostico-rs-2017>. Accessed on: Mar 3, 2020.

SMITH, S. R.; JASIM, S. Small-scale home composting of biodegradable household waste: overview of key results from a 3-year research program in West London. Waste Management and Research, v. 27, n. 10, p. 941-950, 2009. https://doi.org/10.1177\%2F0734242X09103828

SOLID WORKS. Design Software. 2016. 9000 version. Dassault Systems. 2016.

TATÀNO, F.; PAGLIARO, G.; DI GIOVANNI, P.; FLORIANI, E.; MANGANI, F. Biowaste home composting: Experimental process monitoring and quality control. Waste Management, n. 38, p. 72-85, 2015. https://doi.org/10.1016/j. wasman.2014.12.011

UNIVERSITY OF MISSOURI. Making and Using Compost. Columbia: University of Missouri, 2010. Available at: <https://extension.missouri.edu/ publications/g6956>. Accessed on: Mar 3, 2020. 